\title{
Construction of concept map on the physiotherapeutic evaluation in the rheumatic patients: an experience report
}

\author{
Nailton Benjamim Júnior1, Gabriele Natane de Medeiros Cirne', Adriano Araújo de Carvalho', Laiza Oliveira Mendes de Melo, \\ Maria Clara Silva Barbosa', Yuri Medeiros Silva', Marcelo Cardoso de Souza'
}

\begin{abstract}
Introduction: The construction of concept maps should be carried out considering a hierarchical structuring of the concepts that will be presented. The mapping is a technique that can be used in various situations. Objective: the objective of this study is to construct a concept map within the perspective of the physiotherapy evaluation in rheumatology and to report the students' experience in this learning process. Method: This study is an experience report by the students of the tenth period of the Physiotherapy course from the Faculty of Health Sciences at Trairi/Federal University of Rio Grande do Norte, who were in activities of the Rheumatological Physiotherapy Internship, held in the school clinic of physiotherapy of the institution. A total of six students developed their concept maps using the CmapTools 6.01 software. Results: We can observe through the students' reports that they understood the importance of using this type of tool as a way to improve and optimize learning. Conclusions: Experience reports show that indeed the construction of the concept map brings positive effects in the rescue of theoretical content and facilitates clinical practice.
\end{abstract}

Keywords: Educational Technology; Rheumatology; Physiotherapy.

\section{INTRODUCTION}

The concept maps were created by Joseph Novak in order to instrumentalize the theory of the learning, which proposes to explain the internal mechanisms of the human mind, in relation to the learning and structure of knowledge. ${ }^{(1,2)}$ The construction of these concept maps must be performed considering a hierarchical structuring of the concepts that will be presented, through a progressive differentiation and integrative reconciliation. ${ }^{(3,4)}$

Progressive differentiation refers to the unfolding of a particular concept in other concepts that are contained within it, starting from more global concepts to more inclusive concepts. $^{(5)}$

In turn, integrative reconciliation corresponds to the relation of a concept to an apparently disparate one, in which a concept of one branch of the root is interconnected with another concept of another branch from the same root. ${ }^{(4)}$

Conceptual mapping is a very flexible technique and can be used in several situations, for different purposes such as: learning resource, evaluation method, didactic technique, among others. ${ }^{(6)}$

It is also used as a facilitating instrument for student learning as well as for specialists to make clear the connections that they perceive among the concepts about a certain theme. ${ }^{(5)}$
In physiotherapeutic evaluation of the rheumatic patient it is necessary to approach a large number of variables, which makes it such a complex and extensive evaluation.

Taking into account these characteristics with the need for objectivity in the physiotherapeutic routine, and thinking of contributing towards viable methods to direct professionals and students in performing this type of evaluation, which are reproducible in rheumatology, we think of the use of conceptual maps as a method for assist in the evaluation procedures of patients with rheumatic diseases.

Thus, the objective of this study is to construct a concept map within the perspective of the physiotherapy evaluation in rheumatology and to report the students' experience in this learning process.

\section{METHOD}

This study is an experience report by the students of the tenth period of the Physiotherapy course from the Faculty of Health Sciences at Trairi/Federal University of Rio Grande do Norte, who were in activities of the Rheumatological Physiotherapy Internship, held in the school clinic of physiotherapy of the institution.

At the end of each day of the internship there was a moment of discussion about the activities developed during the day.

Corresponding Author: Name: Marcelo Cardoso de Souza Address: Rua Vila Trairi, S/N, Centro, Santa Cruz - RN - CEP: 59200-000 E-mail: marcelocardoso@facisa.ufrn.br 1 Universidade Federal do Rio Grande do Norte, Faculdade de Ciências da Saúde do Trairi, Santa Cruz (RN), Brazil.

Financial support: None.

Submission date 9 September 2016; Acceptance date 29 November 2016; Publication online date 15 December 2016 
At the first moment of discussions, the teacher/supervisor of the internship proposed the elaboration of a concept map encompassing the main aspects to be approached in the physiotherapeutic evaluation of a rheumatic patient, including anamnesis, physical examination and complementary aspects. The guiding question for the elaboration of the map was: what are the most important items that should be observed during the physiotherapeutic evaluation of the rheumatic patient?

The students had seven days to studying, researching in books, articles and database to prepare the concept map.

Thus, a total of six students who were from the group of trainees developed individually their concept maps using the CmapTools 6.01 software, a tool widely known and used for the elaboration of this type of material. ${ }^{(7)}$ There was no training for use of the software and students were challenged to seek strategies for handling the software, as there are tutorials that explain how it should be used.

In a second moment, the trainees met with the supervisor of the internship to present and discuss the concept maps produced, in which they discussed the common aspects exposed in each map and the need for adaptations in some of them, besides the idea of unifying the maps in one for the use of all.

It was also carried out the collection of reports of the students and the supervisor of the internship, in order to evaluate the impact of the mapping in the clinical practice of the students.

\section{RESULTS AND DISCUSSION}

Below we present the final version of the concept map elaborated by the internship students (Figure 1).

The figure 1 summarizes in a didactic way the main variables of the physiotherapeutic evaluation of patients with rheumatic diseases. These main variables were distributed in 7 main axes, as shown in the map from right to left:

Axis 1- Anamnesis/main complaint, stiffness and pain: We should focus on the characteristics of the pain of the patient and duration of stiffness. These data are important to know how much pain the patient feels at the time of the evaluation.

Axis 2- Inspection: At this moment of the evaluation, we should seek all visible changes (gait, skin, asymmetries) that may influence the biomechanical aspects of the patient.

Axis 3- Palpation: We should palpate the pain sites, touch the patient, feel the local temperature, altered sensitivity and note all the changes found.

Axis 4- Evaluation of the arc of movement: It must be performed actively, because passively can be harmful and more painful to the patient. Goniometry is always indicated for future comparison.

Axis 5- Assessment of muscle strength: Patients usually have muscle weakness.

Axis 6- Evaluation of functionality: This important item should be performed through questionnaires or functional tests. Indicate the functional status of the patient and how the therapist should focus on their treatment.

Axis 7- Evaluation of complementary tests: Important to make correlations with the clinic, but we should remember that the clinical examination is often more important and richer than the imaging tests.

Chronic diseases comprise a set of conditions that are usually related to multiple causes, characterized by gradual onset, usually with uncertain prognosis, with long or indefinite duration. They present a clinical course that changes over time, with possible periods of exacerbation, which may lead to disability. They require interventions associated with lifestyle changes, in a process of continuous care that does not always lead to cure. . $^{(8,9)}$

Among the most common chronic diseases are rheumatic diseases, which are expressed with numerous characteristics, thus requiring a more detailed evaluation. In rheumatology, given the systemic conditions that the patient presents, it is important for the physiotherapist to clearly determine the patient's involvement. Thus, it is fundamental to elaborate a kinetic-functional diagnosis according to the clinical condition of the patient, identifying the dysfunctions and associating

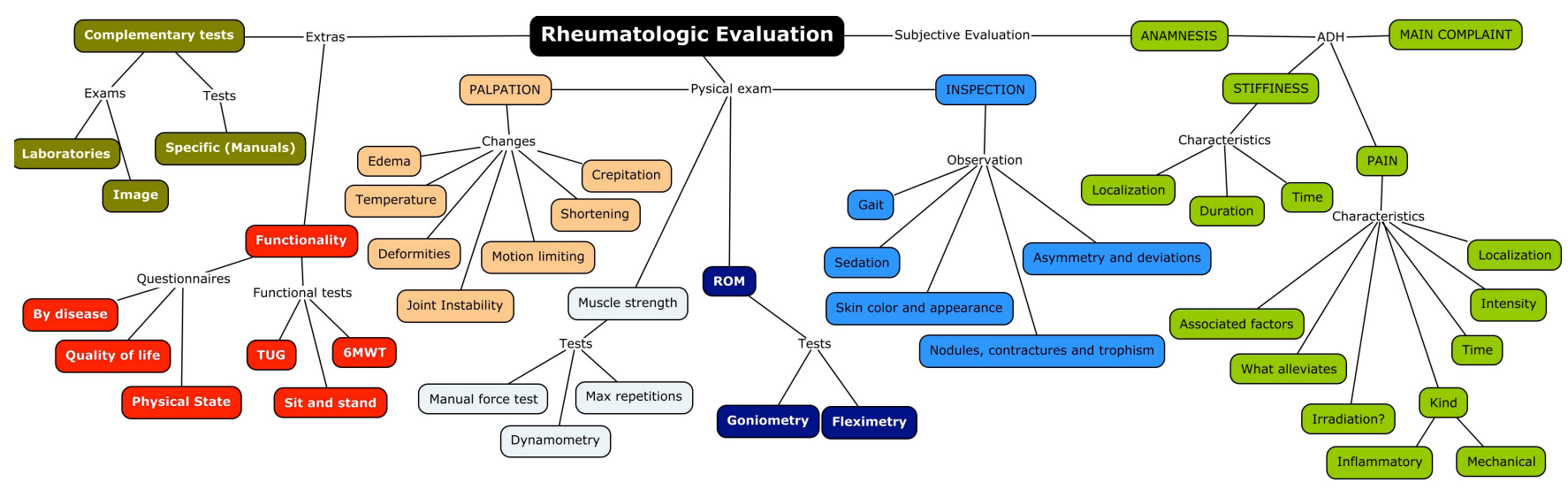

Figure 1: Concept map of physiotherapeutic evaluation of the rheumatic patient. 
them with the information obtained from the anamnesis, the physical examination, the functional evaluation and the complementary tests presented. When an incomplete diagnosis is made, there will be flaws in the treatment objectives and, consequently, the treatment will also be incomplete. ${ }^{(10,11)}$

In this study, we used the concept map as a tool to direct and organize the main variables of the physiotherapeutic evaluation of patients with rheumatic diseases. These main variables were distributed in 7 main axes according to the different colors of the map: anamnesis/main complaint, inspection, palpation, evaluation of the arc of movement, muscle strength, functionality and complementary tests.

It is known that there are different types of concept maps, with different graphical distributions, so there is no model that is considered more correct or more indicated than other. In this study, it was observed the use of the hierarchical concept map. It functions as a facilitator of learning, through which the student learns to learn and visualizes gaps in the understanding of a certain theme, which favors the search for additional information to clarify the concepts. ${ }^{(12,13)}$

Besides the elaborated map we also present the reports by the students and the supervisor of the internship.

Student 1: "The experience of constructing a concept map for the physiotherapeutic evaluation of rheumatologic patients provides a broad knowledge about the signs and symptoms of these patients, since with the elaborate scheme of the map, we can perceive a range of possibilities of investigating the disorders caused by the disease. Thus, providing more options for interpretation of clinical findings and with a good evaluation can provide a better and more specific care."

Student 2: "The development of a concept map on the evaluation of rheumatologic patient allowed the direct union of all the important aspects of a rheumatologic evaluation, clarifying some important aspects related mainly to the current pain state of the patient. We can verify the importance of an initial and final evaluation with these patients."

Student 3: "I thought the preparation of concept map of great enrichment for our physiotherapy practice, since reproduces clearly and objectively the main points to be noted for evaluation and treatment in rheumatology, easy to remember and to trace conducts. I confess that I was scared at first because I did not know the software, but the methodology employed forced us to study and research to elaborate the map."

Student 4: "The construction of the concept map was a very positive exercise to recall the important questions for the evaluation of the rheumatologic patient, and help in the determination of the theoretical content of the evaluation."

Student 5: "The famous concept maps are actually more than maps, but ideas of study, organogram of overflowed thoughts. For the simple reader, the concept map is just a diagram that indicates relationships between concepts or words, but for those who elaborate it is the result of multiple concepts and ideas that have been evaluated and reassessed, chosen and unmasked until everything is clear and represents a clear and objective way the subject exhaustively studied. When I was able to elaborate the concept map of physiotherapy evaluation for patients with rheumatic diseases, I was obliged not only to stick to the techniques or concepts, but to enter and recall the pathophysiological characteristics of the diseases, their correlations between symptoms and signs, etiological characteristics, customs and common complaints of patients and the degree of effectiveness of the techniques, and only then have a way to trace."

Student 6: "Being able to construct a tool that facilitates and directs the evaluations in the clinical practice, as the concept maps, it was of great relevance for my formation as future professional of the health the methodology used, since after this practice I had more facility to carry out the evaluations of the patients, as well as to outline the objectives and conduct for each case."

Professor of the internship: "Knowing that the patient with rheumatic disease demands a careful evaluation and with many variables, the objective of bringing all these concepts to the construction of a map, is to provide clarity in the student's thinking during the physiotherapeutic evaluation process in these patients. I consider the methodology satisfactory to be used in the clinical practice of students and also professionals".

Despite the different ways of reporting the experience of constructing a concept map for evaluation of rheumatic patient, we can observe in the reports of the students that they understood the importance of using this type of tool as a way to improve and optimize learning, besides develop critical thinking, which is understood as a careful, deliberate and focused on results, motivated by the needs of the patient, the family, and the community. ${ }^{(14)}$

As well as the study of Bittencourt et $a l .{ }^{(15)}$ in the present study, the students who had it not previously in their routine, adhere it well to organize and schematize the ideas of the proposed theme in a way that there was articulation between different modes and indicated an understanding of the theme.

The development of tools such as concept maps requires concentration, study and commitment. Although concept maps, like any other evaluation strategy, does not constitute a perfect strategy in terms of the amount of time required to construct them, ${ }^{(16)}$ since it is agreed that meaningful learning depends on the pre-disposition to learn, ${ }^{(17)}$ the map shows that for those who elaborate it, a good understanding of the subject to be exposed is essential, being seen as a challenge. This idea is confirmed when we observe the report of "Student 5 " which he needed to recall relevant characteristics that should be considered when evaluating a patient with rheumatic disease.

Concept maps can facilitate learning by summarizing information. ${ }^{(18)}$ When compared to text summaries, concept maps can be revised more quickly, allowing students to review 
information several times over a fixed period of time. ${ }^{(18)}$ By presenting models, concepts and links in an organized way, concept maps show information and allow students to manage and resemble a large amount of information. ${ }^{(19)}$ However, recent study of learning in physiotherapy, showed that the conceptual knowledge may be necessary, but it is not sufficient to guide the resolution of problems. ${ }^{(20)}$

The greatest difficulty found in the conceptual mapping was the time required to research and study the keywords that should be included in the map assembly, as well as the use of the software, first seen by the students. At the end of the elaboration, the students reported that the therapeutic conduct and the organization of the thought regarding the range of variables used in the evaluation of the patient were much more logical and easy to understand. This was indeed the most important in this process, since the goal was to make it more efficient, improve and facilitate patient evaluation.

\section{CONCLUSION}

The construction of this concept map on the physiotherapeutic evaluation of the rheumatic patient was an important process in the teaching-learning context for the students of the internship of Physiotherapeutic Attention in Rheumatology. Experience reports show that the constructing of concept map has positive effects on the retrieval of theoretical content facilitating clinical thinking during the physiotherapeutic evaluation of patients with rheumatic diseases, and the student contemplate all variables to obtain a complete evaluation.

\section{AUTHOR'S CONTRIBUTION}

Nailton Benjamim Júnior, Gabriele Natane de Medeiros Cirne, Adriano Araújo de Carvalho, Laiza Oliveira Mendes de Melo, Maria Clara Silva Barbosa, Yuri Medeiros Silva: "data collection, manuscript preparation, final review". Marcelo Cardoso de Souza - "interpretation of data, study orientation, final review".

\section{CONFLICTS OF INTEREST}

The author(s) declare that they have no competing interests.

\section{REFERENCES}

1- Pelizzari A, KriegI ML, Baron MP, Finck NTL, Dorocinski SI. Teoria da aprendizagem significativa segundo Ausubel. Psicologia Educação e Cultura. 2002;2(1):37-42.
2- Moreira MA, Masini EFS. Aprendizagem Significativa: A teoria de David Ausubel, São Paulo: Centauro Editora; 2009.

3- Novak JD. Conocimiento e Aprendizaje: Los mapas conceptuales como herramientas facilitadoras para escuelas y empresas. Madrid: Editorial Alianza; 1998.

4- Novak JD, Gowin, DB. Aprender a aprender. Lisboa: Plátano Edições Técnicas; 1999.

5- Tavares R. Construindo mapas conceituais. Ciências \& Cognição. 2007; (12):72-85.

6- Moreira MA, Buchweitz B. Novas estratégias de ensino e aprendizagem: os mapas conceituais e o Vê epistemológico. Lisboa: Plátano Edições Técnicas; 1993.

7- Ferreira PB, Cohrs CR, Domenico EBL. Software CMAP TOOLS ${ }^{\circ}$ para a construção de mapas conceituais: a avaliação dos estudantes de enfermagem. Rev. Esc. Enferm. 2012; 46(4):967-72.

8- Ministério da Saúde (Br). Secretaria de Atenção à Saúde. Departamento de Atenção Básica. Diretrizes para o cuidado das pessoas com doenças crônicas nas redes de atenção à saúde e nas linhas de cuidado prioritárias. Brasília (DF): Ministério da Saúde; 2013.

9- Rosa DJF, Machado RF, Fraga RO, Scotton AS, Souza VA, Fernandes B. Eritema elevatum diutinum como diagnóstico diferencial das doenças reumatológicas: relato de caso. Rev Bras Reumatol 2012;52(2):288-94.

10- Garcia W. Coletânea de Questões e Habilidades Gerais e Específicas do ENADE - Medicina / Wander Garcia - Campinas, SP : Editora Foco, 2013.

11- Carvalho MAP, Bértolo MB, Lanna CCD. Reumatologia: Diagnóstico e Tratamento.3 ed. Rio de Janeiro: Guanabara Koogan, 2008.

12- Tavares R. Construindo mapas conceituais. Ciênc Cogn. 2007;12(4):72-85.

13- Balduino AFA, Gomes IM, Lacerda MR, Mantovani MF. A utilização de mapas conceituais no estudo de um referencial metodológico: relato de experiência. Ciência, Cuidado e Saúde. 2013; 12(1):177-83.

14- Alfaro-Lefevre R. Aplicação do processo de enfermagem: uma ferramenta para o pensamento crítico. Porto Alegre: Artmed; 2010.

15- Bittencourt GKGD, Nóbrega MML, Medeiros ACT, Furtado LG. Mapas conceituais no ensino de pós-graduação em enfermagem: relato de experiência. Rev Gaúcha Enferm. 2013;34(2):172-176.

16- Turns J, Atman CJ, Adams R. Concept maps for engineering education: a cognitively motivated tool supporting varied assessment functions. IEEE Transactions on Education. 2000; 43(2): 164-173.

17- Moreira MA, Masini EFS. Aprendizagem significativa. A teoria de David Ausubel. São Paulo: Centauro. 2006.

18. Nesbit JC, Adesope OO. Learning with concept and knowledge maps: a meta-analysis. Rev Educ Res. 2006;76(3):413-48.

19- Henige $\mathrm{K}$. Use of concept mapping in an undergraduate introductory exercise physiology course. Adv Physiol Educ. 2012;36(3):197-206.

20- Dyer JO, Hudon A, Montpetit-Tourangeau K, Charlin B, Mamede S, van Gog T. Example-based learning: comparing the effects of additionally providing three different integrative learning activities on physiotherapy intervention knowledge. BMC Med Educ. 2015 Mar 7;15:37. 